\title{
Role of trace elements in the 226-Radium incorporation in sulfate minerals
}

(gypsum and celestite)

Leslie Lestini $^{\mathrm{a}, \mathrm{b}, \mathrm{c}}$, Catherine Beaucaire ${ }^{\mathrm{a}, \mathrm{b},{ }^{*}}$, Thomas Vercouter ${ }^{\mathrm{a}}$, Marine Ballinic, Michaël Descostes ${ }^{c}$

${ }^{a}$ CEA, DEN, Physico Chemistry Departement, F-91191 Gif-sur-Yvette, France

${ }^{b}$ Laboratory Analysis and Modelling for Biology and Environment, Evry University, CNRS, CEA, UMR 8587, Bd. Francois Mitterrand,F-91025 Evry, France

${ }^{c}$ AREVA Mines - R\&D Dpt, Tour AREVA, 1 Place Jean Millier, 92084 Paris La Défense, France

* Corresponding author. Tel.: +33-(0)1-69-08-59-79; fax: +33-(0)1-69-08-75-03

E-mail address: catherine.beaucaire@cea.fr

To be submitted in Environmental Science and Technology 


\begin{abstract}
Incorporation of ${ }^{226} \mathrm{Ra}$ within gypsum $\left(\mathrm{CaSO}_{4} \cdot 2 \mathrm{H}_{2} \mathrm{O}_{(\mathrm{s})}\right)$ and celestite $\left(\mathrm{SrSO}_{4(\mathrm{~s})}\right)$ was assessed through dedicated batch experiments monitored over hundreds of days. Results indicate that the published value for the distribution coefficient of ${ }^{226} \mathrm{Ra}$ between gypsum and an aqueous phase, $\mathrm{D}_{\mathrm{Ra}}$, gypsum $=0.03$ is an upper limit. On the other hand, celestite shows high incorporation of the radionuclide, with partition coefficient around 200 . This high ${ }^{226} \mathrm{Ra}$ uptake by celestite results from the existence of a solid solution between celestite and radium sulfate, as expected considering the similarities between the two solids, as between barite and radium sulphate. On the contrary, a solid solution between gypsum and radium sulfate $(\mathrm{Ca}, \mathrm{Ra}) \mathrm{SO}_{4} \cdot 2 \mathrm{H}_{2} \mathrm{O}_{(\mathrm{s})}$ cannot be considered per se, due mainly to the fact they do not behave in the same crystal family. However, ${ }^{226} \mathrm{Ra}$ incorporation in gypsum can be enhanced by the presence of $\mathrm{Sr}$ impurities (from 0.1 molar\%). In such conditions, the radium distribution coefficient is around $0.15 \pm 0.09$. This behavior can be explained by an ion-exchange mechanism between ${ }^{226} \mathrm{Ra}$ and $\mathrm{Sr}$. These results highlight the key role of trace elements in the incorporation of ${ }^{226} \mathrm{Ra}$ in sulphate bearing minerals and bring new insights in our understanding of the ${ }^{226} \mathrm{Ra}$ in environment.(as illustrated with an example in mining context...)
\end{abstract}

Keywords: radium; gypsum; celestite; solid solution; distribution coefficient 


\section{INTRODUCTION}

As a decay product of the ${ }^{238} \mathrm{U}$ decay chain, ${ }^{226} \mathrm{Ra}$ is naturally present in the uranium ore. Due to its relative high half-period (1620 y), ${ }^{226} \mathrm{Ra}$ is predominant among other Ra isotopes. It is commonly encountered in groundwaters ${ }^{1,2}$, deposits in oil pipelines ${ }^{3}$ or in desalinization plants of seawater ${ }^{4}$. According to its half period, and its high specific activity, ${ }^{226} \mathrm{Ra}$ is one of the main contaminants of concern (COC) in the uranium mining industry ${ }^{5,6}$.The abundance of ${ }^{226} \mathrm{Ra}$ is generally so low, in the range of ppb, that no proper mineral phase has ever been found in natural environments. As a trace element, its mobility can then only be lowered by interactions with surrounding mineral phases present in its environment. It is actually well known that its behaviour is mainly controlled by surface interactions onto clays ${ }^{7,8}$, carbonates ${ }^{9}$, metal oxides ${ }^{10}$ or amorphous phase ${ }^{11}$ and primary minerals altered. The fate of ${ }^{226} \mathrm{Ra}$ can also be controlled by solid solution formation processes ${ }^{12}$. As sulfate minerals are very common natural phases found in most sedimentary environments, they give rise to a particular interest in their ability or not to fix radium. ${ }^{226} \mathrm{Ra}$ was reported to be associated with sulfate minerals: gypsum in the case of uranium mill tailings ${ }^{13}$, barite/celestite in brines from evaporation ponds of desalinisation plant ${ }^{14}$, or barite in potential high-level radioactive waste repositories ${ }^{15}$. Barite $\left(\mathrm{BaSO}_{4}\right)$ is the main sulphate phase that forms solid solution with ${ }^{226} \mathrm{Ra}$ as first reported by Marie Curie $^{16}$, and investigated by several researchers ${ }^{13,17,18,19,20}$.

${ }^{226} \mathrm{Ra}$ can enter the barite lattice, either by coprecipitation or incorporation, to form a solid solution compound, $\mathrm{Ba}_{(1-\mathrm{x})} \mathrm{Ra}_{\mathrm{x}} \mathrm{SO}_{4}(\mathrm{~s})$. Such solid solutions were studied by different experimental approaches 15,17,18. Although more differences exist between $\mathrm{Ra}^{2+}$ and other divalent alkaline-earth elements like $\mathrm{Sr}^{2+}, \mathrm{Ca}^{2+}, \mathrm{Mg}^{2+}$, solid solution formation has been considered as well. A few studies by coprecipitation experiments with gypsum have been reported for the Ca- $\mathrm{Ra}-\mathrm{SO}_{4}-\mathrm{H}_{2} \mathrm{O}$ system ${ }^{14,21,22}$, and to our knowledge, only two experimental studies reported the coprecipitation of ${ }^{226} \mathrm{Ra}$ with celestite in the $\mathrm{Sr}-\mathrm{Ra}-\mathrm{SO}_{4}$ system ${ }^{23,24}$. Interactions between ${ }^{226} \mathrm{Ra}$ and minerals of the barite isostructural family $\left(\mathrm{MeSO}_{4}\right)$ are usually described by the distribution coefficient $\mathrm{D}_{\mathrm{Ra}}$, mineral according to:

$$
D_{226 \text { Ra,mineral }}=\frac{\left(\frac{{ }^{226}[\mathrm{Ra}]}{[\mathrm{Me}]}\right) \text { solid }}{\left(\frac{{ }^{226}[\mathrm{Ra}]}{[\mathrm{Me}]}\right) \text { aqueous }}
$$

Where $\left(\left[{ }^{226} \mathrm{Ra}\right] /[\mathrm{Me}]\right)_{\text {solid }}$ and $\left(\left[{ }^{226} \mathrm{Ra}\right] /[\mathrm{Me}]\right)_{\text {aqueous }}$ represent the molar ratio in the solid and in the solution, respectively, between ${ }^{226} \mathrm{Ra}$ and $\mathrm{Me}$, the major element substituted.

The experimental studies of the $\mathrm{RaSO}_{4}-\mathrm{BaSO}_{4}$ system provided $\mathrm{D}_{\mathrm{Ra}}$, barite values between 0.3 and 1.8 , the highest values being obtained via coprecipitation experiments ${ }^{17,18}$, and the lowest value, obtained 
recently via incorporation study ${ }^{15,20}$. For the $\mathrm{RaSO}_{4}-\mathrm{CaSO}_{4} \cdot 2 \mathrm{H}_{2} \mathrm{O}$ system, $\mathrm{D}_{\mathrm{Ra}}$, gypsum values are ranging from $0.03^{21}$ to $0.3^{22}$. A much higher $\mathrm{D}_{\mathrm{Ra}}$, celestite value of 340 has been reported for the $\mathrm{RaSO}_{4}-\mathrm{SrSO}_{4}$ system from coprecipitation experiment ${ }^{23}$. However, in recent studies ${ }^{24}$, experimental $\mathrm{D}_{\mathrm{Ra}}$, celestite values are varying from 43 to below 1.0.

The apparent discrepancy between the $D_{R a}$ values for each chemical system makes it difficult to establish a satisfactory model of ${ }^{226} \mathrm{Ra}$ behavior with time. It is worth noting that too little attention has been given to ${ }^{226} \mathrm{Ra}$ interaction with celestite, for which the distribution coefficient $\mathrm{D}_{\mathrm{Ra}}$, celestite seems to be very high according to Goldschmidt's report ${ }^{23}$.

The purpose of this study is to re-examine the distribution coefficient of ${ }^{226} \mathrm{Ra}$ between aqueous solutions and both gypsum and celestite, conducting incorporation experiments under near equilibrium conditions. Moreover the fact that minerals are rarely pure led us to consider additional experiments where ${ }^{226} \mathrm{Ra}$ incorporation is studied in sulfate minerals in presence of impurities. Among impurities, Sr is known to incorporate gypsum.

\section{Material AND MethodS}

Two types of experiment were performed: firstly, incorporation experiments aim to estimate the rate of ${ }^{226} \mathrm{Ra}$ incorporation in pure solid $\left(\mathrm{CaSO}_{4} \cdot 2 \mathrm{H}_{2} \mathrm{O}\right.$ and $\left.\mathrm{SrSO}_{4}\right)$, and secondly co-precipitation experiments to evaluate the potential role of solid impurities on ${ }^{226} \mathrm{Ra}$ incorporation.

\subsection{Incorporation experiments}

The incorporation experiment of ${ }^{226} \mathrm{Ra}$ in a solid near equilibrium conditions consists of following the evolution of ${ }^{226} \mathrm{Ra}$ activity over time in the aqueous solution in contact with the solid phase initially free of ${ }^{226} \mathrm{Ra}$. The methodology was previously detailed elsewhere ${ }^{15}$. The trace element is incorporated in the solid through a dissolution/recrystallization process characteristic of the dynamic equilibrium stated between the solid and the solution. As the trace element incorporation in the solid phase depends on the dissolution/recrystallization rate, a kinetic monitoring of such processes is necessary. This is achieved by following the uptake of a radioisotope of the major element substituted by the solid. In fact, introducing this radioisotope in the solution creates an isotopic disequilibrium that will be balanced by incorporation of an amount of the radioisotope in order to reach the dilute isotopic equilibrium. So the same process as in the radium incorporation study is monitored, and gives access to the amount of solid recrystallized on a time scale. ${ }^{45} \mathrm{Ca}$ has been selected for the gypsum monitoring, while ${ }^{85} \mathrm{Sr}$ has been selected for celestite monitoring.

The dilute isotopic balance between the solid phase and the aqueous phase can be described by an exponential law':

$$
\mathrm{A}(\mathrm{t}) / \mathrm{A}_{0}(\mathrm{t})=\exp -\left([\mathrm{S} / \mathrm{L} \cdot \Omega \cdot \sigma \cdot \mathrm{t}] /[\mathrm{Me}]_{\text {saturation }}\right)
$$


where $\mathrm{A}(\mathrm{t})$ et $\mathrm{A}_{0}(\mathrm{t})$ represent the activity of radiolabeled metal $* \mathrm{Me}\left({ }^{45} \mathrm{Ca},{ }^{85} \mathrm{Sr}\right)$ in the solution and the initial activity remaining in solution at the sampling time $t$, respectively. The natural radioactive decay of $* \mathrm{Me}$ is taken into account. $\mathrm{S} / \mathrm{L}$ represents the solid:liquid ratio $\left(\mathrm{g} . \mathrm{L}^{-1}\right), \quad \Omega$ is the dissolution/recrystallization rate $\left(\mathrm{mol} \cdot \mathrm{m}^{-2} \cdot \mathrm{day}^{-1}\right), \sigma$ is the specific surface of the solid $\left(\mathrm{m}^{2} \cdot \mathrm{g}^{-1}\right)$, $[\mathrm{Me}]_{\text {saturation }}$ is the $\mathrm{Me}(\mathrm{Ca}, \mathrm{Sr})$ concentration in the solution equilibrated with the solid, and $\mathrm{t}$ is the interaction time (day). The $\mathrm{S} / \mathrm{L}$ and $[\mathrm{Me}]_{\text {saturation }}$ parameters are assumed to be constant during the experiment; $\sigma$ is also assumed constant with time. The recrystallization rate is then obtained by fitting the $*$ Me activity data with time.

On the one hand, incorporation experiments were run with synthetic gypsum, precipitated from a supersaturated solution, and commercial celestite (Sigma-Aldrich; pure at 99\%). Analysis of minerals showed that celestite is particularly rich in $\mathrm{Ba}(1000 \mathrm{ppm})$, when gypsum contains only Sr impurities (70 ppm). On the other hand, incorporation experiments were run with natural gypsum (Italy), containing around $270 \mathrm{ppm}$ of $\mathrm{Sr}$, and $20 \mathrm{ppm}$ of $\mathrm{Pb}$. All solid phases were characterized by powder XRD analysis (Inel XRG 3000 diffractometer) and by BET (Micromeritics ASAP 2010) surface experiment with $\mathrm{N}_{2}$ prior to the experiments. Specific surface of synthetic, natural gypsum and celestite are respectively found at $0.6,2$ and $3 \mathrm{~m}^{2} \cdot \mathrm{g}^{-1}$.

For each system studied, ${ }^{226} \mathrm{Ra}$-gypsum system and ${ }^{226} \mathrm{Ra}$-celestite system, the ${ }^{226} \mathrm{Ra}$ incorporation study and the recristallization experiment have been run in separate batch solutions. For the first system, two sets of ten batches of $10 \mathrm{~mL}$ each, with a solid:liquid (S/L) ratio of $32 \mathrm{~g} . \mathrm{L}^{-1}$, have been prepared: one spiked with ${ }^{226} \mathrm{Ra}$ tracer (IPL source), the other with ${ }^{45} \mathrm{Ca}$ tracer (Cerca source). The slurries were then mounted on rotating end-over-end shakers to provide a continuous mixing. At regular time intervals, the batch solutions were centrifuged during $1 \mathrm{~h}$ at $20000 \mathrm{rpm}$. After filtration, ${ }^{226} \mathrm{Ra}$ was analyzed by gamma spectrometry, using an $\mathrm{N}$-type high coaxial purity germanium detector (ITECH-Instruments) in airtight plastic container $(50 \mathrm{~mL})$ at $186.21 \mathrm{keV}$. The InterWinner@6.0 software was used to calculate the activities taking into account the father-son decay law. The detection limit is estimated at $10 \pm 5 \mathrm{~Bq}$ or $1.10^{-12}$ moles.

${ }^{45} \mathrm{Ca}$ was measured by liquid scintillation (Packard TRI-CARB 2500TR). For each set, 3 standards have been prepared with only the solution in equilibrium with gypsum and spiked in the same way as the suspensions. Solutions are diluted with UltimaGold LT in a ratio 1/5.

For the second system, incorporation experiments were carried out in a single batch of $0.6 \mathrm{~L}$ in presence of synthetic celestite, with a S/L ratio of 0.07 g.L. $\mathrm{L}^{-1}$ and spiked with ${ }^{226} \mathrm{Ra}$. Recrystallization experiments are realized in ten batch solutions of $20 \mathrm{~mL}$ each, with a $\mathrm{S} / \mathrm{L}$ ratio of $1.5 \mathrm{~g} . \mathrm{L}^{-1}$, and spiked with ${ }^{85} \mathrm{Sr}$ (Cerca source). ${ }^{85} \mathrm{Sr}$ was measured by gamma counting (WIZARD 3"1480). The experimental conditions are summarized in table 1.

\subsection{Co-precipitation experiments}


Besides incorporation experiments, different experiments of co-precipitation were carried out in order to test the role of trace elements impurities in sulfate solids on the ${ }^{226} \mathrm{Ra}$ incorporation rate. ${ }^{226} \mathrm{Ra}$ incorporation was studied in the $\mathrm{Ca}-\mathrm{Sr}_{\mathrm{Trace}}-\mathrm{SO}_{4} \cdot 2 \mathrm{H}_{2} \mathrm{O}$ system. Batch experiments were obtained by mixing a solution of $\mathrm{CaCl}_{2}\left(>99.0 \%\right.$, FLUKA $\left.{ }^{\circledR}\right)$ and $\mathrm{SrCl}_{2}, 6 \mathrm{H}_{2} \mathrm{O}\left(>99.0 \%\right.$ ALDRICH®) with $\mathrm{Na}_{2} \mathrm{SO}_{4}$ (>99.0\% ALDRICH®) in a final volume of $20 \mathrm{~mL} .{ }^{226} \mathrm{Ra}$ was incorporated in the solution just before adding $\mathrm{Na}_{2} \mathrm{SO}_{4}$ reactant in order to have an initial activity of around $300 \mathrm{~Bq} / \mathrm{mL}$. Influence of state of over-saturation (from 1.18 to 1.4 ) with respect to the more soluble solid phase $\left(\mathrm{CaSO}_{4} \cdot 2 \mathrm{H}_{2} \mathrm{O}\right)$ was investigated by the choice of different concentrations of the major element $(\mathrm{Ca})$. Different concentrations of trace element $(\mathrm{Sr})$ were investigated maintaining the molar $\mathrm{Sr} / \mathrm{Ca}$ ratio almost constant $(\sim 0.003)$ and as high as possible to avoid too large over-saturation with respect to celestite Quantities of precipitated gypsum were calculated from the initial and final concentration of $\mathrm{Ca}$ measured in batchs. Analyses of cations were realized by ion chromatography (IC Metrohm Vario 850). The uncertainty is estimated at $2 \%$. Sr at trace level was analysed by ICP-MS (Varian 810 ). Detection limit is estimated at $10^{-11} \mathrm{~mol} / \mathrm{L}$ with an uncertainty of $5 \% .{ }^{226} \mathrm{Ra}$ activity was counted by $\gamma$ spectrometry.

In order to perform observations on $\mathrm{Ca}-\mathrm{Sr}_{-} \mathrm{SO}_{4}$ solids (X-rays diffractometry), some experiments were carried out in the absence of ${ }^{226} \mathrm{Ra}$. Experimental conditions are summarized in supporting information (table SI-1).

Table 1: Experimental conditions of recrystallization experiments.

\begin{tabular}{|c|c|c|c|c|c|c|}
\hline Solid & Spike & $\begin{array}{c}\mathrm{S} / \mathrm{L} \\
\left(g . L^{-1}\right)\end{array}$ & $\begin{array}{c}\text { Volume } \\
(m L)\end{array}$ & $\begin{array}{c}\text { Duration } \\
\text { (days) }\end{array}$ & $\begin{array}{c}{[\mathrm{Ca}]_{\mathrm{sat}}} \\
\left(\mathrm{mmol} . \mathrm{L}^{-1}\right)\end{array}$ & $\begin{array}{c}{[\mathrm{Sr}]_{\mathrm{sat}}} \\
\left(\mathrm{mmol} \mathrm{L}^{-1}\right)\end{array}$ \\
\hline \multicolumn{7}{|c|}{ Recrystallization Experiment } \\
\hline I-GS1 Synth. gypsum & ${ }^{45} \mathrm{Ca}$ & 32 & 10 & 200 & 15 & \\
\hline I-GS2 Synth. gypsum & ${ }^{45} \mathrm{Ca}$ & 32 & 10 & 200 & 15 & \\
\hline I-GN Nat. gypsum & ${ }^{45} \mathrm{Ca}$ & 32 & 10 & 200 & 15 & \\
\hline I-CS4 Synth. celestite & ${ }^{85} \mathrm{Sr}$ & 1.5 & 20 & 60 & & 0.7 \\
\hline \multicolumn{7}{|c|}{ Incorporation Experiments } \\
\hline I-GS1 Synth. gypsum & ${ }^{226} \mathrm{Ra}$ & 32 & 10 & 200 & 15 & \\
\hline I-GS2 Synth. gypsum & ${ }^{226} \mathrm{Ra}$ & 32 & 10 & 200 & 15 & \\
\hline I-GN Nat. gypsum & ${ }^{226} \mathrm{Ra}$ & 32 & 10 & 200 & 15 & \\
\hline I-CS1 Synth. celestite & ${ }^{226} \mathrm{Ra}$ & 0.07 & 600 & 66 & & 0.7 \\
\hline I-CS2 Synth. celestite & ${ }^{226} \mathrm{Ra}$ & 0.07 & 600 & 129 & & 0.7 \\
\hline I-CS3 Synth. celestite & ${ }^{226} \mathrm{Ra}$ & 0.07 & 600 & 159 & & 0.7 \\
\hline
\end{tabular}




\section{RESUlTS}

\subsection{Incorporation experiments}

\section{Gypsum}

The data set obtained with the ${ }^{45} \mathrm{Ca}$ incorporation experiments in gypsum shows a significant decrease of the radioisotope solution activity with time consistent with the ongoing dissolution/recrystallization processes occurring in the solid (Fig. 1). Two successive trends can be individuated, suggesting two different recrystallization rates: a first one until approximately 10 days, and a slower one, from ten days of contact time until 200 days. Concurrently, ${ }^{226} \mathrm{Ra}$ activity in the solution $\left(\mathrm{A}^{226} \mathrm{Ra}\right.$ ) shows no evolution with time considering the uncertainty of the measurement (Fig. 2).

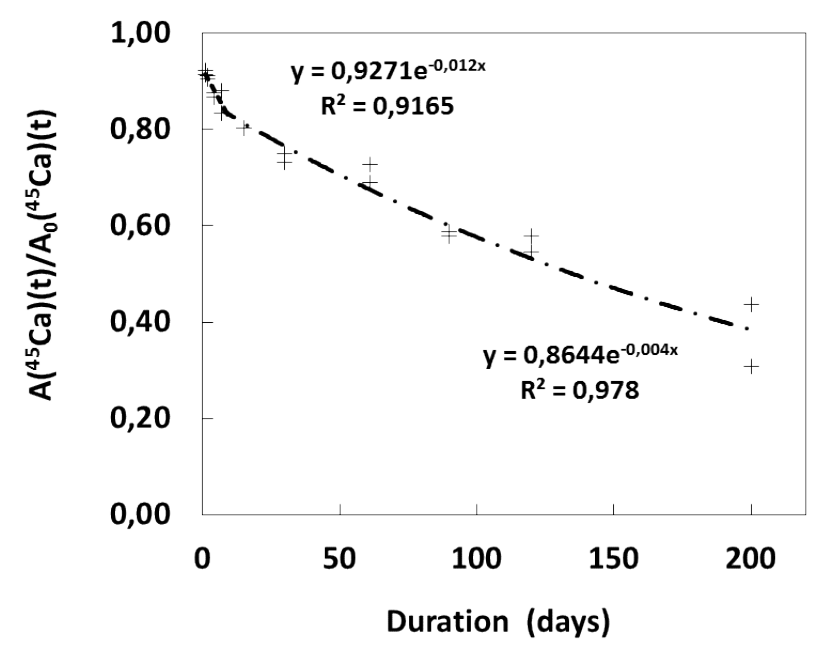

Fig. 1. Evolution of $\mathrm{A}\left({ }^{45} \mathrm{Ca}\right)(\mathrm{t}) / \mathrm{A}_{0}\left({ }^{45} \mathrm{Ca}\right)(\mathrm{t})$ ratio with time in solution at equilibrium with gypsum.

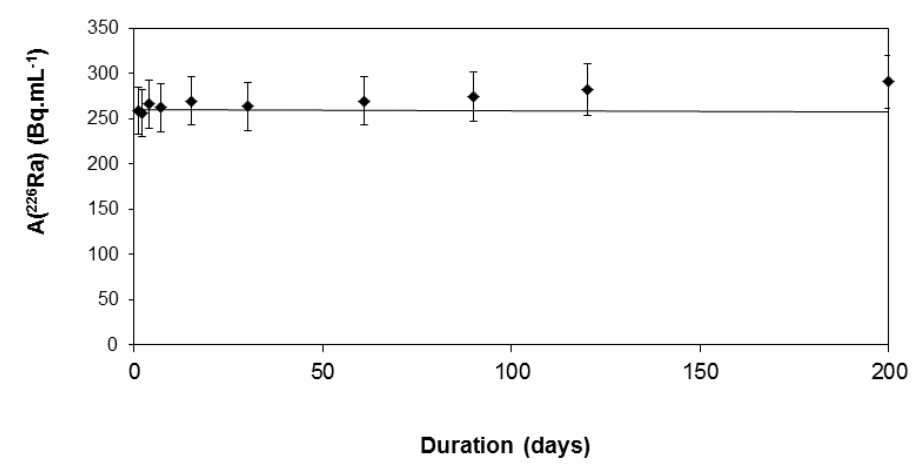

Fig. 2: Evolution of ${ }^{226} \mathrm{Ra}$ activity with time in solution at equilibrium with gypsum. Simulation of ${ }^{226} \mathrm{Ra}$ incorporation in $\mathrm{CaSO}_{4} \cdot 2 \mathrm{H}_{2} \mathrm{O}$ is given for a $\mathrm{D}_{\mathrm{Ra}}$, gypsum value of $0.03^{21}$.

${ }^{45} \mathrm{Ca}(\mathrm{t}) /{ }^{45} \mathrm{Ca}_{0}(\mathrm{t})$ ratio plotted against time shows the presence of two successive rates, with a transition occurring approximately 10 days after ${ }^{226} \mathrm{Ra}$ spiking (Fig. 1). The fit of the experimental results according to Eq. (2) leads to the estimation of a first dissolution/recrystallization rate of $1.14 .10^{-5}$ 
mol. $\mathrm{m}^{-2} \cdot \mathrm{d}^{-1}$ between 1 and 10 days and a second one of $3 \cdot 92 \cdot 10^{-6} \mathrm{~mol} \cdot \mathrm{m}^{-2} \cdot \mathrm{d}^{-1}$ between 10 and 200 days of experiment.

These values have been obtained considering a constant solid to liquid ratio $(\mathrm{S} / \mathrm{L})$ of 31.4 g.. $\mathrm{L}^{-1}$, a specific surface of $0.5 \mathrm{~m}^{2} \cdot \mathrm{g}^{-1}$ and a $[\mathrm{Ca}]_{\text {saturation }}$ of $1.5 .10^{-2} \mathrm{M}$. As previously mentioned ${ }^{25}$, microscopic observations showing dehydration figures at the solid surface led to the conclusion that the prolonged time of the solid in the stove during the preparation stage, has conducted to its dehydration and formation of bassanite $\left(\mathrm{CaSO}_{4} \cdot 0,5 \mathrm{H}_{2} \mathrm{O}\right)$. This was confirmed by XRD characterization. Therefore, the first rate corresponds to the solid rehydration, while the second rate characterizes the dissolution/recrystallization processes occurring in the solid under equilibrium conditions.

The amount of newly formed solid (recrystallized) $[\mathrm{Ca}]_{\text {solid }}$ in moles during the experiment can be estimated as follows:

$$
[\mathrm{Ca}]_{\mathrm{solid}}=\Omega \cdot \sigma \cdot \mathrm{m} \cdot \mathrm{t}
$$

where $\mathrm{m}$ represents the mass of solid introduced in solution (g). Over 200 days of experiment, about $2.10^{-2} \mathrm{~g}$ of gypsum have been recrystallized ( $7 \%$ of the initial solid). Results obtained on natural and other synthetic gypsum are not shown here but led to similar conclusions. Incorporation of ${ }^{226} \mathrm{Ra}$ remains negligible despite that the quantities of recrystallized gypsum can represent up to $23 \%$ of the initial solid.

According to the uncertainties on ${ }^{226} \mathrm{Ra}$ analysis and the stability of ${ }^{226} \mathrm{Ra}$ concentration in solution with time, it is impossible to determine the amount of ${ }^{226} \mathrm{Ra}$ incorporated in the solid and therefore the coefficient distribution, according to the following relation:

$$
\left[{ }^{226} \mathrm{Ra}\right]_{\text {solid }}=\mathrm{D}_{\mathrm{Ra}} \text {, gypsum }\left[\left[^{226} \mathrm{Ra}\right]_{\text {solution }} \cdot[\mathrm{Ca}]_{\text {solid }} /[\mathrm{Ca}]_{\text {solution }}\right.
$$

However an estimation of the distribution coefficient is given in the 3.2 Section through coprecipitation experiment.

\section{Celestite}

The data collected via the recristallization experiment run with ${ }^{85} \mathrm{Sr}$ on the celestite show a significant decrease of ${ }^{85} \mathrm{Sr}$ solution activity with time, suggesting a fast incorporation in the solid (Fig. SI-1). The dissolution/recristallization rate, obtained by fitting the data and considering a specific surface of 3 $\mathrm{m}^{2} \cdot \mathrm{g}^{-1}$ and a solid:liquid ratio of $1,48 \mathrm{~g} \cdot \mathrm{L}^{-1}$, is $1.72 \mathrm{~mol} \cdot \mathrm{m}^{-2} \cdot \mathrm{d}^{-1}$. We estimated that $6 \%$ to $14 \%$ of the solid has recrystallized over the period of time studied depending on the experimental set considered.

Unlike in the Ra-Gypsum system, the ${ }^{226} \mathrm{Ra}$ uptake experiments run on celestite shows a significant and rapid decrease of ${ }^{226} \mathrm{Ra}$ solution activity with time, reproducible over the three experiments. The incorporation stabilized at about $40 \%$ of the initial ${ }^{226} \mathrm{Ra}$ present in the solution. This threshold is reached between 10 and 20 days of experiment (figure 3 ). 


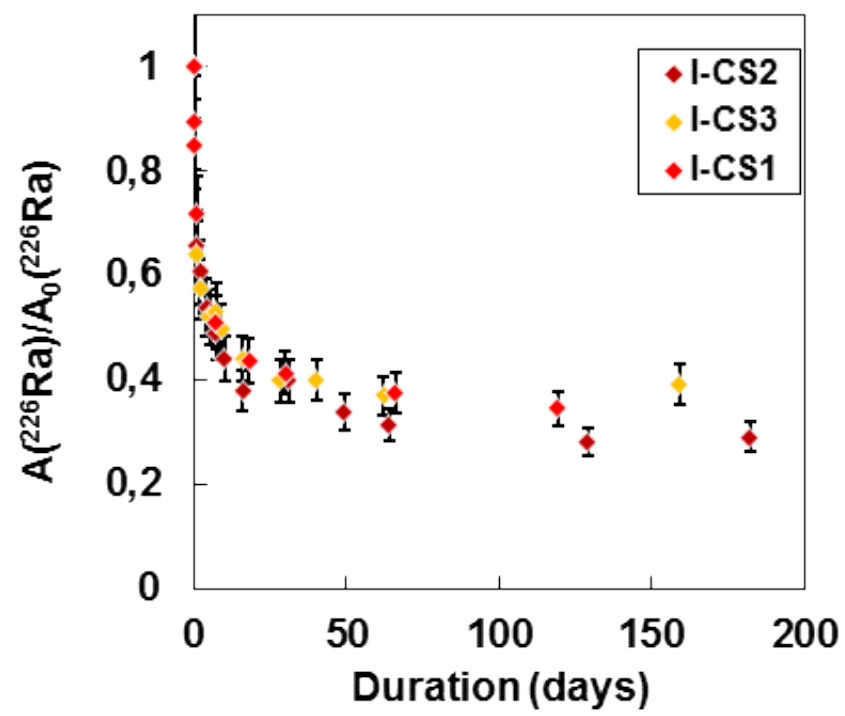

Figure 3: Evolution of ${ }^{226} \mathrm{Ra}$ activity normalized to the initial activity $\left(\mathrm{A}_{0}\right)$ with time in solution at equilibrium with celestite

\subsection{Co-precipitation experiments}

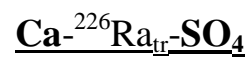

Whatever the initial conditions and experiment duration, the initial ${ }^{226} \mathrm{Ra}$ concentration remains constant with time confirming the results obtained during recrystallization experiments. However, in order to evaluate the $\mathrm{D}_{\mathrm{Ra}}$, gypsum value, the quantity of radium adsorbed on solid was determined by alpha spectrometry over a long time of counting. Total activity of ${ }^{226} \mathrm{Ra}$ in gypsum is estimated at 13.3 $\pm 2.7 \mathrm{~Bq} / \mathrm{g}$. The $\mathrm{D}_{\mathrm{Ra}}$, gypsum value is therefore found at $(8.8 \pm 1.5) \cdot 10^{-4}$, slightly below the value estimated in evaporitic natural samples ${ }^{4}$ (i.e. 0.003).

$\underline{\mathrm{Ca}-\mathrm{Sr}_{\underline{t r}}}{ }_{\underline{2}}{ }^{226} \mathrm{Ra}_{\underline{t r}}-\underline{S O}_{4}$

Experimental results of $\mathrm{Sr}$ co-precipitation with gypsum are summarized in the supporting information (table SI-2). Various over-saturation states of the initial solutions with respect to gypsum (from 1.18 to 1.4) and initial $\mathrm{Sr}$ concentration (from 0.2 to $3.0 \mathrm{mmol} / \mathrm{L}$ ) were tested. The $\mathrm{Sr}$ incorporation rate in gypsum is varying from 3 to $35 \%$ of initial $\mathrm{Sr}$ content. Values of $\mathrm{D}_{\mathrm{Sr} \text {, gypsum }}$ are found between 0.1 and 0.45 and are slightly correlated with the $\mathrm{Sr} / \mathrm{Ca}$ molar ratio in gypsum (see figure SI-2). For a same initial oversaturation state with respect to gypsum, a higher initial $\mathrm{Sr}$ concentration gives a higher $\mathrm{Sr} / \mathrm{Ca}$ in gypsum. These values are close to the observations reported in previous experimental studies carried out, in brine conditions and at different rate of crystallization ${ }^{27}$, with an estimated value of $\mathrm{D}_{\mathrm{Sr}}$, gypsum around 0.1 at equilibrium.

Contrary to the experimental run in absence of $\mathrm{Sr},{ }^{226} \mathrm{Ra}$ is slightly more incorporated in gypsum in presence of $\mathrm{Sr}$ impurities. The quantity of precipitated solid was calculated from the mass balance measured on calcium. In the same way the amount of radium incorporated in the solid is calculated 
from the mass balance measured on radium. The data set obtained with the ${ }^{226} \mathrm{Ra}$ uptake experiments by gypsum in presence of $\mathrm{Sr}$ impurities show that, as previously observed in the $\mathrm{Ca}-\mathrm{Sr}-\mathrm{SO}_{4}$ system,

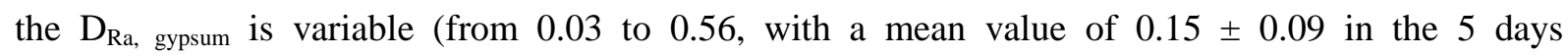
experimental run, table 2). The $\mathrm{Sr} / \mathrm{Ca}$ in gypsum remains low, inferior to 1 molar\%. However, for similar initial chemical conditions, we note that the variability of $D_{R a, \text { gypsum }}$ values is reduced after 5 days of equilibration compared to 24 hours of equilibration.

Table 2: Summary of experimental results obtained for ${ }^{226} \mathrm{Ra}$ incorporation in gypsum in presence of $\mathrm{Sr}$ impurities (co-precipitation experiments), for 1 day (1-6) and 5 days (1a-6a) of interaction. S.I.: saturation index.

\begin{tabular}{|c|c|c|c|c|c|c|c|c|}
\hline Run & 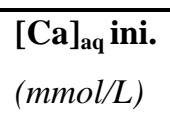 & $\begin{array}{c}{[\mathbf{C a}]_{\mathrm{aq} \cdot} \text { end }} \\
(\mathrm{mmol} / \mathrm{L})\end{array}$ & $\begin{array}{c}\mathbf{C a}_{\text {solid }} \\
(\mathrm{mmol})\end{array}$ & $\begin{array}{c}{ }^{\left.{ }^{226} \mathbf{R a}\right]_{\text {aq. }} \text { ini. }} \\
(B q / m L)\end{array}$ & $\begin{array}{c}{\left[^{226} \mathbf{R a}\right]_{\mathrm{aq}} \cdot \text { end }} \\
(B q / m L)\end{array}$ & $\begin{array}{c}{ }^{226} \mathbf{R a}_{\text {solid }} \\
(\mathrm{mmol})\end{array}$ & S.I. & $\mathbf{D}_{\text {Ra, gypsum }}$ \\
\hline 1 & 55 & 33.02 & 0.65 & 317.9 & 230.4 & $2.1 \mathrm{e}-10$ & 1.35 & 0.56 \\
\hline 2 & 56 & 21.6 & 0.68 & 314.0 & 307.5 & $1.6 e-11$ & 1.35 & 0.013 \\
\hline 3 & 167 & 100.41 & 1.33 & 312.3 & 238.0 & $1.80 \mathrm{e}-10$ & 1.46 & 0.47 \\
\hline 4 & 165.5 & 93.19 & 1.44 & 303.3 & 280.1 & $5.7 e-11$ & 1.46 & 0.1 \\
\hline 5 & 275 & 164.8 & 2.21 & 311.5 & 286.2 & $6.2 \mathrm{e}-11$ & 1.40 & 0.13 \\
\hline 6 & 826 & 592.4 & 4.65 & 307.6 & 279.2 & $6.9 \mathrm{e}-11$ & 1.18 & 0.26 \\
\hline $1 \mathbf{a}$ & 55.5 & 18.7 & 0.73 & 308.8 & 261.7 & $1.1 \mathrm{e}-10$ & 1.35 & 0.09 \\
\hline $2 a$ & 58.5 & 17.1 & 0.82 & 309.3 & 262.3 & $1.1 \mathrm{e}-10$ & 1.36 & 0.07 \\
\hline $3 \mathbf{a}$ & 166 & 104.7 & 1.21 & 310.2 & 268.3 & $1.0 \mathrm{e}-10$ & 1.46 & 0.27 \\
\hline $4 a$ & 165.5 & 104.3 & 1.21 & 311.9 & 272.2 & $9.7 e-11$ & 1.46 & 0.25 \\
\hline $5 \mathbf{a}$ & 273.5 & 118.2 & 3.10 & 313.3 & 299.8 & $5.6 e-11$ & 1.40 & 0.03 \\
\hline $6 a$ & 825 & 536.6 & 5.74 & 317.5 & 290.8 & $6.5 \mathrm{e}-11$ & 1.18 & 0.17 \\
\hline
\end{tabular}

\section{Discussion}

\subsection{Sr and ${ }^{226} \mathrm{Ra}$ incorporation in Gypsum}

The experimental results reported on a diagram showing the evolution of ${ }^{226} \mathrm{Ra}$ solution activity with time (black dots) indicate no decrease of this activity over 200 days (Fig. 2). The results are compared with the simulation obtained for a $\mathrm{D}_{\mathrm{Ra}}$, gypsum value of 0.03 , indicating that the experimental $\mathrm{D}_{\mathrm{Ra}}$, gypsum value is more likely to be very low. Other sorption/desorption and coprecipitation experimental results have shown no evolution of ${ }^{226} \mathrm{Ra}$ activity neither in the solution nor in the solid with time, suggesting that these two other mechanisms are not more efficient than incorporation in reducing ${ }^{226}$ Ra mobility by interactions with gypsum.

Several arguments can be proposed to explain this absence of interactions between ${ }^{226} \mathrm{Ra}$ and gypsum: the two main criteria governing element substitution are the ion charge and the ionic radius. Whereas calcium and radium have the same ion charge $(+2)$, the difference between their ionic radii in eight- 
coordination (Ca coordination number in gypsum) is significantly high: $1.12 \AA$ for $\mathrm{Ca}$ and $1.7 \AA$ for ${ }^{226} \mathrm{Ra}$. Therefore, ${ }^{226} \mathrm{Ra}$ appears to be too large to enter Ca site in gypsum crystal lattice.

In the case of binary (Me-Tr) solid solutions, equilibrium is defined by two mass-actions equations,

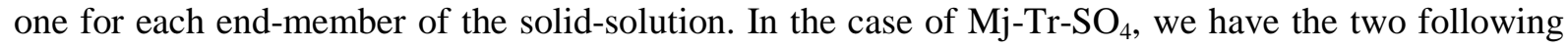
equilibria:

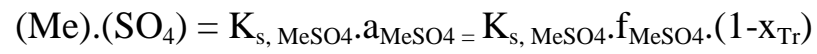

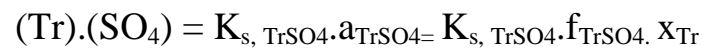

Where $\mathrm{K}_{\mathrm{s}, \mathrm{MeSO} 4}$ and $\mathrm{K}_{\mathrm{s}, \mathrm{TrSO} 4}$ are respectively the solubility products of the two end-members, and $\mathrm{f}_{\mathrm{MeSO} 4}$ and $\mathrm{f}_{\mathrm{TrSO} 4}$ are respectively the activity coefficients of $\mathrm{Me}$ and $\mathrm{Tr}$ in the solid solution and ( ) the activities of species in solution. $\mathrm{X}_{\mathrm{Tr}}$ is defined as the molar fraction of $\mathrm{TrSO}_{4}$ in solid solution.

By combining the two relations (5) and (6), it is admitted in the case of isomorphous substitution mechanisms in solid solution, at equilibrium, that the theoretical values of the $\operatorname{Tr}$ (trace) partition coefficient in a host mineral can be expressed as:

$$
D_{T r}, \text { mineral }=\frac{\left(\frac{[\mathrm{Tr}]}{[\mathrm{Me}]}\right) \text { solid }}{\left(\frac{[\mathrm{Tr}]}{[\mathrm{Me}]}\right) a q u .}=\frac{K_{S, \mathrm{MeSO} 4}}{K_{S, T r S O}} \frac{\gamma_{T r}}{\gamma_{M e}} \frac{f_{M e S O 4}}{f_{T r S O 4}}
$$

This relation lies on the fact that the two end-members crystallize in the same system. In this case, effectiveness of the $\operatorname{Tr}$ incorporation is more important as the $\operatorname{Tr}$ endmember solubility is lower than the one of the host.

In the case of $\mathrm{Ra}$ and $\mathrm{Sr}$, the two respective end-members crystallize in orthorhombic system when gypsum crystallizes in the monoclinic system. That is likely the main reason for which $\mathrm{Sr}$ and $\mathrm{Ra}$ are poorly incorporated in gypsum. 
In the case of the $\mathrm{Sr}$ incorporation in gypsum, the measured distribution coefficients, comprised between 0.1 and 0.5 (see 3.2), are very low compared to a theoretical value calculated from the solubility-products ratio (i.e. around 120), implying that solid solution departs highly from ideality. Despite the fact that $\mathrm{Ca}$ and $\mathrm{Sr}$ have similar ionic radius (respectively 1.12 and $1.48 \AA$ ), and due to the fact that end-members do not crystallize in the same system, the most probable interstitial lattice positions were among the hydration water molecules ${ }^{26}$. However according to XRD pattern obtained on Sr-doped (around 5\% molar) biogenic gypsum ${ }^{27}$, it was observed a significant shift to lower diffraction angle when $\mathrm{Sr}$ concentrations increased indicating that $\mathrm{Sr}$ ions are incorporated into lattice structure of gypsum crystals. In the present study, we did not observe any shift, due probably to the very low rate of $\mathrm{Sr}$ incorporation (less of $1 \%$ ).

It remains that, in our experimental conditions, we can relate without ambiguity the incorporation of ${ }^{226} \mathrm{Ra}$ in gypsum to the presence of $\mathrm{Sr}$ in lattice positions with a partition coefficient $\mathrm{D}_{\mathrm{Ra}}$, gypsum around $0.15 \pm 0.09$, involving likely cation exchange process. Note also that in presence of low Sr content (around $270 \mathrm{ppm}$ ) in natural gypsum we did not observe any incorporation of ${ }^{226} \mathrm{Ra}$ during previous experiments.

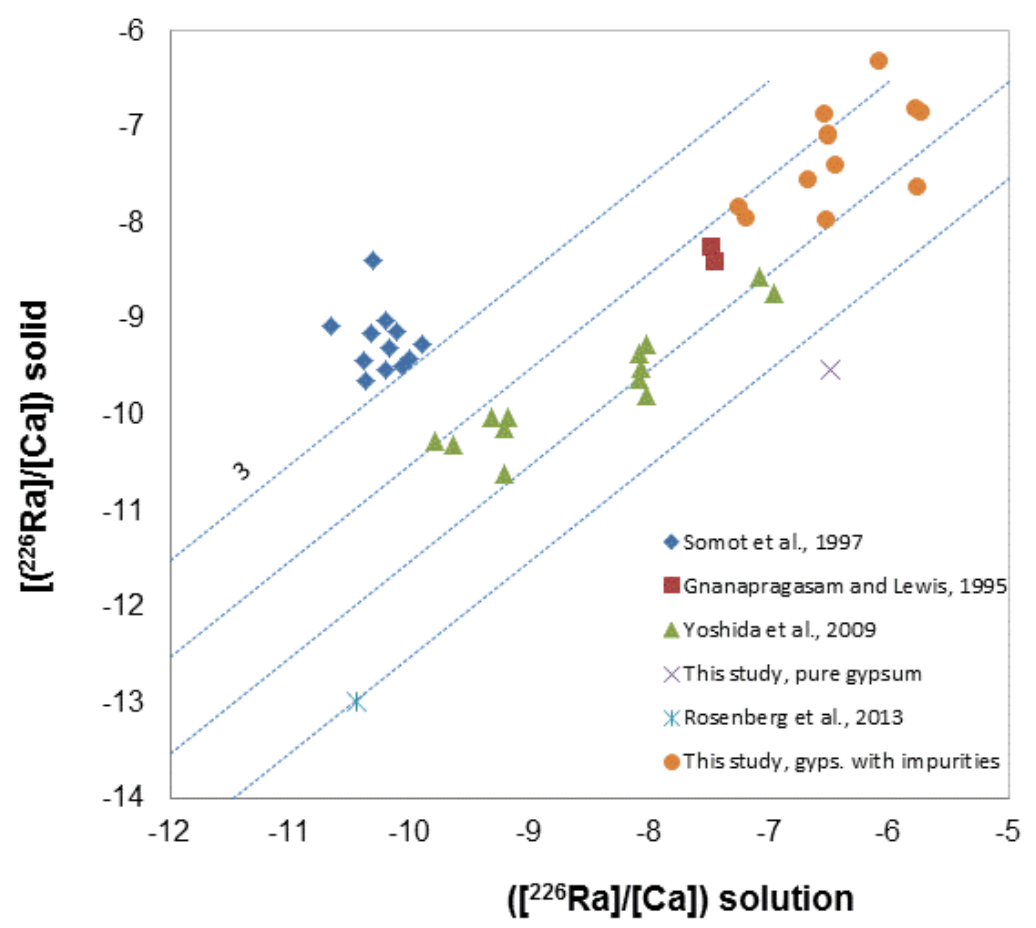

Figure 4: Comparison of $D_{R a, g y p s u m}$ in literature with values obtained in this study. Note that Sr impurities concentrations are comprised between 2000 and 20000 ppm in this study, against 70 ppm in pure gypsum and $270 \mathrm{ppm}$ in natural gypsum. 
We can conclude that ${ }^{226} \mathrm{Ra}$ is not significantly incorporated into pure gypsum. A very low value of the homogeneous distribution coefficient of radium into gypsum has been determined of $(9 \pm 2) \cdot 10^{-4}$, which is much lower than all the values available in the literature. In other words, a solid solution between gypsum and radium sulfate $(\mathrm{Ca}, \mathrm{Ra}) \mathrm{SO}_{4} \cdot 2 \mathrm{H}_{2} \mathrm{O}$ cannot be considered per se. However in presence of $\mathrm{Sr}$ impurities ( 0.1 to $1 \mathrm{molar} \%),{ }^{226} \mathrm{Ra}$ can be quantitatively incorporated in gypsum, leading to distribution coefficient mainly comprised between 0.03 and 0.3 (see figure 4). These values are in the same order of those previously determined in literature through co-precipitation experiments $^{21,22}$ but lower than the highest values estimated through sequential leaching ${ }^{13}$.

\subsection{Ra incorporation in Celestite}

As for gypsum, the experimental data permit the evaluation of the newly recrystallized solid amount, $\mathrm{n}_{\text {recrystallised }}$ (moles; equation 3) from which is calculated the molar fraction $x_{R a}$ (ss) of ${ }^{226} \mathrm{RaSO}_{4(\mathrm{~s})}$ in the solid according to:

$x_{R a}(\mathrm{SS})=\frac{[226 R a]_{0}-[226 R a]_{t}}{n_{\text {recrystallized }} / V}$

Where $[\mathrm{Ra}]_{0}$ and $[\mathrm{Ra}]_{\mathrm{t}}$ are respectively the Ra concentrations in solution at the start of experiment and at sampling time $\mathrm{t}, \mathrm{V}$ being the solution volume.

The homogeneous empirical distribution coefficient of ${ }^{226} \mathrm{Ra}$ between celestite and an aqueous solution is given by the following relation:

$D_{R a, \text { celestite }}=\frac{x_{R a}(\mathrm{ss})[\mathrm{Sr}]}{\left(1-x_{R a}(\mathrm{ss})\right)\left[{ }^{226} R a\right] t}$

Considering that ${ }^{226} \mathrm{Ra}$ is incorporated at trace concentration, the $\mathrm{Sr}$ concentration, $[\mathrm{Sr}]$, is close to the $\mathrm{Sr}$ concentration at equilibrium with pure celestine, $\left[{ }^{226} \mathrm{Ra}\right]_{\mathrm{t}}$ is the Ra concentration at sampling time.

The $\mathrm{D}_{R a \text {, celestite }}$ calculated are very high, and at the first stage of the experiments, they happen to be close to the thermodynamic value, given by the relation (10).

$D_{R a, \text { celestite }}=\frac{K_{S, S r S O 4}}{K_{S, R a S O 4}} \frac{\gamma_{R a}}{\gamma_{S r}} \frac{f_{\text {SrSO }}}{f_{\text {RaSO }}}$

with $\log \mathrm{K}_{\mathrm{s}, \mathrm{SrSO} 4}=-6.63$ and $\log \mathrm{K}_{\mathrm{s}, \mathrm{RaSO} 4}=-10.26$. 
In the case of ideal solid-solution, $f_{\mathrm{SrSO}_{4}}$ and $f_{\mathrm{RaSO} 4}$, the activity coefficients in the solid-solution equal to unity. According to this formula, $\mathrm{D}_{R a \text {, celestite }}$ takes the high value of 4266 . This indicates that, if in the first steps of interactions between ${ }^{226} \mathrm{Ra}$ and celestite, they could be assigned to pure exchange between ${ }^{226} \mathrm{Ra}$ and $\mathrm{Sr}$ in the crystal lattice, the further processes involved are more complex, and cannot be considered only of pure exchange, but probably involve structural modifications of the crystals while integrating ${ }^{226} \mathrm{Ra}$ in the structure.

As defined in relation (10), except in the ideal case, distribution coefficient is not constant and depends of both composition of aqueous solution and solid solution. In conditions close to equilibrium as in the case of recrystallization experiments, D variation is mainly due to the evolution of solid solution composition and is a function of the rate of Tr-Me substitution.

The activity coefficients of $\mathrm{RaSO}_{4}$ and $\mathrm{SrSO}_{4}, \mathrm{f}_{\mathrm{RaSO}}$ and $\mathrm{f}_{\mathrm{SrSO}}$ are calculated applying the Henry and Raoult's law respectively, in the case of regular solid solution (see supplementary information). This is possible because the results obtained are for very diluted solutions. This means that $\mathrm{x}_{\mathrm{Ra}}<0.001$, so $\operatorname{lnf}_{\mathrm{Ra}}$ is approximately $\mathrm{a}_{0}$, and $\operatorname{lnf}_{\mathrm{Sr}}$ is approximately 0 .

In the present case, the non-ideality parameter, $\mathrm{a}_{0}$, has been graphically determined at 3 (see figure SI3 ), and is close to the value calculated with GM Selektor ${ }^{28}$ for the solid solution $\mathrm{Sr}-\mathrm{Ba}_{-} \mathrm{SO}_{4}$. This value led to an estimation of Margules parameter $\mathrm{W}$ at around $1834 \mathrm{cal}^{\mathrm{mol}}{ }^{-1}$, close to the value estimated through the semi-empirical correlation established by $\mathrm{Zhu}^{19}$ (i.e. $1931 \mathrm{cal}^{\mathrm{mol}}{ }^{-1}$ ).Consequently the equilibrium distribution coefficient $\mathrm{D}_{R a \text {, celestite }}$ is estimated according to the following relation ${ }^{15}$

$a_{0}=\ln \left(\frac{K_{S, \text { SrSO } 4}}{K_{S, \text { RaSO } 4} D_{\text {Ra,celestite }}}\right)$

at around 200, for $\mathrm{x}_{\mathrm{Ra}}(\mathrm{ss}) \sim 0.001$, against 280 from Goldschmidt's study ${ }^{18}$, or 228 from Zhu's study ${ }^{19}$.The $\mathrm{D}_{R a \text {, celestite }}$ values recently obtained through co-precipitation experiments at different ionic strengths $^{24}$, are comprised between 43 for less of $10 \%$ of initial Sr removal in celestite to below 1 for more than $90 \%$ of Sr removal. The high discrepancy observed, for relatively short reaction times (48 hours), between the theoretical value corrected from Margules parameter (i.e. 237) and the measured value is attributed by the authors to the kinetic limit for ${ }^{226} \mathrm{Ra}$ inclusion in celestite. In co-precipitation experiments, the observed distribution coefficient usually differs from the one established at equilibrium conditions, and principally for high degree of over-saturation. Therefore, it is generally observed that composition of solid solution is enriched in the more soluble component ${ }^{28}$. 
In conclusion, celestite, sulfate mineral with an intermediate solubility product between gypsum and barite ones, appears to be a good host for ${ }^{226} \mathrm{Ra}$. The experimental results show that radium uptake by this mineral phase is significant, and the ${ }^{226}$ Ra-celestite system seems to behave as non-ideal solid solution. For low $\mathrm{x}_{\mathrm{Ra}}(\mathrm{ss})(\sim 0.001)$ generally expected in natural environment, $\mathrm{D}_{\mathrm{Ra}}$, celestite is estimated at around 200.

This study illustrated also that presence of impurities in mineral sulphate can drastically impact the behavior of ${ }^{226} \mathrm{Ra}$. This is the case for gypsum with $\mathrm{Sr}$ impurities. Other sulphate can also incorporate impurities such as very common $\mathrm{Ba}-\mathrm{Sr}-\mathrm{SO}_{4}$ solid solution. Through experiments of ${ }^{226} \mathrm{Ra}$ incorporation in celestite, in presence of different amounts of Ba impurities (not shown here) we verified that the distribution coefficients of ${ }^{226} \mathrm{Ra}$ in celestite is not influenced by Ba impurities ( up to $1 \mathrm{~mol} \%$ of $\mathrm{Ba}$ in celestite). Conversely, in natural brines it has been observed that even in presence of $\mathrm{Sr}$, if baryum is present, barite being more insoluble than celestite, barite remains the principal reservoir of ${ }^{226} \mathrm{Ra}^{4}$. All these results have to be taken into account in the understanding of the ${ }^{226} \mathrm{Ra}$ fate in natural and anthropized environments.. 


\section{References:}

(1) Beaucaire, C. ; Toulhoat, P. Redox chemistry of uranium and iron, radium geochemistry, and uranium isotopes in the groundwaters of the Lodeve Basin, Massif Central, France. Applied Geochemistry 1987, 2, 417-426.

(2) Beaucaire, C. ; Criaud, A. ; Michard, G. Contrôle des concentrations de certains éléments trace (As, Sb, Ge, U, Ra, Ba) dans les eaux du Cézallier (Massif Central, France). Chemical Geology, 1987, 63, 85-99

(3) Gazineua,M.H.,P., de Araujoa, A., Brandaoa, Y., B., Hazin, C., A., de O. Godoy, J., M., Radioactivity concentration in liquid and solid phases of scale and sludge generated in the petroleum industry. J. Environ. Radioact. 2005, 81, 47-54.

(4) Rosenberg, Y.O.; Metz, V.; Ganor, J. Radium removal in a large scale evaporitic system; Geochim. Cosmochim. Acta 2013,103, 121-137.

(5)Dejeant, A. ; Bourva, L. ; Sia, R. ; Galoisy, L. ; Calas, G. ; Phrommavanh, V. ; Descostes, M. Field analyses of ${ }^{238} \mathrm{U}$ and ${ }^{226} \mathrm{Ra}$ in two uranium mill tailings piles from Niger using portable HPGe detector. J. Environ. Radioact. 2014,137, 105-112.

(6) Leermakers, M.; Phrommavanh, V.; Drozdzak, J.; Gao, Y.; Nos, J.; Descostes, M. DGT as a useful monitoring tool for radionuclides and trace metals in environments impacted by uranium mining: Case study of the Sagnes wetland in France. Chemosphère 2016, 155, 142-151

(7) Ames, L.L.; McGarrah, J.E.; Walker, B.A. Sorption of trace constituents from aqueous solutions onto secondary minerals. 2. Radium. Clays and Clay Min. 1983, 31(5): 335-342.

(8) Renoso-Maset, E.; Ly, J. Study of uranium(VI) and radium(II) sorption at trace level on kaolinite using a multisite ion exchange model. J. Environ. Radioact. 2016, 157, 136-148

(9) Jones, M.J., Butchins, L.J., Charnock, J.M., Pattrick, R.A.D., Small, J.S., Vaughan, D.J., Wincott, P.L., Livens, F.R., 2011. Reactions of radium and barium with the surfaces of carbonate minerals. Appl. Geochem. 2011, 26, 1231-1238

(10)Sajih

(11) Ames, L.L.; McGarrah, J.E.; Walker, B.A.; Salter, P.F. Uranium and radium sorption on amorphous ferric oxyhydroxide. Chem. Geol. 1983, 40(1-2): 135-148.

(12) Curti, E. Coprecipitation of radionuclides: basic concepts, literature review anf first applications. Technical report 1997, 97-08.

(13) Somot, S.; Pagel, M.; Thiry, J. Speciation of radium in the uranium mill tailings of Escarpière (Vendée-France). C.R. Académie des Sciences/Earth and Planet. Sci. 1997, 352, 111-116.

(14) Rosenberg, Y.O., Metz, V., Ganor, J.,. Co-precipitation of radium in high ionic strength systems: 1. Thermodynamic properties of the $\mathrm{Na}-\mathrm{Ra}-\mathrm{Cl}-\mathrm{SO} 4-\mathrm{H} 2 \mathrm{O}$ system - Estimating Pitzer parameters for RaCl2. Geochim. Cosmochim. Acta 2011, 75(19), 5389-5402.

(15) Curti, E. et al.,. Radium uptake during barite recrystallization at $23+/-2$ degrees $\mathrm{C}$ as a function of solution composition: An experimental Ba-133 and Ra-226 tracer study. Geochim. Cosmochim. Acta 2010, 74(12): 3553-3570.

(16) Curie, M.. Radium and the new concepts in chemistry, Nobel Lecture 1910.

(17) Doerner, H.A.; Hoskins, W.M.M. Co-precipitation of radium and barium sulfates. J. Amer. Chem. Soc. 1925, 47, 662-675.

(18) Langmuir, D.; Riese, A.C. The thermodynamic properties of radium. Geochim. Cosmochim. Acta 1985, 49 (7), 1593-1601.

(19) Zhu, C. Copreicpitation in the barite isostructural family: 1- Binary mixing properties, Geochim. Cosmochim. Acta 2004, 68 (16), 3327-3337.

(20) Brandt, F.; Curti, E.; Klinkenberg, M.; Rozov, K.; Bosbach, D. Replacement of barite by a $(\mathrm{Ba}, \mathrm{Ra}) \mathrm{SO} 4$ solid solution at close-to-equilibrium conditions: A combined experimental and theoretical study. Geochim. Cosmochim. Acta 2015, 155: 1-15.

(21) Gnanapragasam, E.K.; Lewis, B.A.G. Elastic strain energy and the distribution coefficient of radium in solid solutions with calcium salts. Geochim. Cosmochim. Acta 1995, 59(24), 51035111.

(22) Yoshida, Y.; Nakazawa, T.; Yoshikawa, H.; Nakanishi, T. Partition coefficient of Ra in gypsum. J. Radioanal. Nucl. Chem. 2009, 280(3), 541-545. 
(23) Goldschmidt, B. Etude du fractionnement par cristallisation mixte à l'aide des radioéléments. Thèse 1940, Faculté des Sciences de l'Université de Paris (Fance).

(24) Zhang, T.; Gregory, K.; Hammack, R.W.; Vidic, R.D. Co-precipitation of radium with barium and strontium sulfate and its impact on the fate of radium during treatment of produced water from unconventional gas extraction. Environ. Sci. Technol. 2014, 48, 4596-4603.

(25) Lestini, L.; Beaucaire, C.; Vercouter, T.; Descostes, M. Radium uptake by recrystallized gypsum: an incorporation study. Proc. Earth and Planet. Sci. 2014, 7, 479-482.

(26) Kushnir, J. The coprecipitation of strontium, magnesium, sodium, potassium and chloride ions with gypsum. An experimental study. Geochim. Cosmochim. Acta 1980, 44(10): 1471-1482.

(27) Pouria, A.; Bandegani, H.; Pourbaghi-Masouleh, M.; Hesaraki, S.; Alizadeh, M. Physicochemical properties and cellular responses of strontium-doped gypsum biomaterials. Bioinorg. Chem. Appl. 2012, 976495.

(28) Kulick, D.A. Geochemical thermodynamic modelling of ion partitioning. In Ion partitioning in ambient temperature aqueous systems, European Mineralogical Union, 2010, Vol. 10, chapter 3, 65-138,(Eds. M. Prieto and H. Stoll)

(29) Prieto, M.; Astilleros, J.M.; Fernandez-Diaz, L. Environmental remediation by crystallisation of solid solutions. Elements 2013, 9, 195-201

(30) Bruno, J.; Bosbach, D.; Kulick, D.A.; Navrosky, A. Chemical thermodynamics of solid solutions of interest in nuclear waste management (a state-of-the-art report). In chemical thermodynamics, OECD-Nuclear Energy Agency, Data Bank, 2007, vol.10 (eds. F.J. Mompean, M. Illemassene and J. Perrone). Issy-les-Moulineaux (France), pp.1-2.

(31) Prieto, M. Thermodynamics of solid solution-aqueouq solution sytems. Reviews in Mineralogy and Geochemistry 2009, 70, 47-85. 


\section{Supporting informations:}

Table S.I-1: Experimental conditions of co-precipitation experiments.

\begin{tabular}{|c|c|c|c|c|c|}
\hline System Spike & $\begin{array}{c}\text { Volume } \\
\text { (mL) }\end{array}$ & $\begin{array}{l}\text { Duration } \\
\text { (days) }\end{array}$ & $\begin{array}{c}{[\mathrm{Ca}]_{\mathrm{aq} .}} \\
\left(\mathrm{mmol.L^{-1 }}\right)\end{array}$ & $\begin{array}{c}{[\mathrm{Sr}]_{\mathrm{aq} .}} \\
\left(\mathrm{mmol}^{\left.-L^{-1}\right)}\right.\end{array}$ & $\begin{array}{c}{\left[\mathrm{SO}_{4}\right]_{\mathrm{aq} .}} \\
\left(\mathrm{mmol}^{-L^{-1}}\right)\end{array}$ \\
\hline \multicolumn{6}{|c|}{$\mathrm{Ca}^{226} \mathrm{Ra}^{2} \mathrm{SO}_{4} \mathrm{Co}$-precipitation Experiments } \\
\hline & \multirow[t]{2}{*}{20} & 7 & 60 & & 60 \\
\hline & & 14 & & & \\
\hline & \multirow[t]{2}{*}{20} & 8 & 30 & & 30 \\
\hline & & 30 & & & \\
\hline
\end{tabular}

\section{$\mathrm{Ca}-\mathrm{Sr}_{-} \mathrm{SO}_{4} \mathrm{Co}$-precipitation Experiments}

$\begin{array}{lllll}20 & 5 & 66 & 0.2 & 65 \\ 20 & 5 & 66 & 0.3 & 65 \\ 20 & 5 & 66 & 0.5 & 65 \\ 20 & 5 & 66 & 0.5 & 85 \\ 20 & 5 & 200 & 1.0 & 85 \\ 20 & 5 & 200 & 1.2 & 50 \\ 20 & 5 & 200 & 1.8 & 80 \\ 20 & 5 & 200 & 3.0 & 85 \\ 20 & 5 & 250 & 2.5 & 80 \\ 20 & 5 & 300 & 1.0 & 60\end{array}$

Ca-Sr ${ }^{226} \mathrm{Ra}_{-} \mathrm{SO}_{4} \mathrm{Co}$-precipitation Experiments

$\begin{array}{cccccc}{ }^{226} \mathrm{Ra} & 20 & 1 & 66 & 0.2 & 80 \\ { }^{226} \mathrm{Ra} & 20 & 1 & 66 & 0.2 & 80 \\ { }^{226} \mathrm{Ra} & 20 & 1 & 200 & 0.5 & 80 \\ { }^{226} \mathrm{Ra} & 20 & 1 & 200 & 0.98 & 80 \\ { }^{226} \mathrm{Ra} & 20 & 5 & & & 80 \\ { }^{226} \mathrm{Ra} & 20 & 1 & 330 & 0.98 & 240 \\ & & 5 & & & \\ & & 5 & 985 & 2.9 & \\ \end{array}$


Table SI-2: Sr incoroporation in gypsum by co-precipitation.

\begin{tabular}{|c|c|c|c|c|c|c|c|c|}
\hline$[\mathrm{Ca}]_{\mathrm{aq} \cdot}$ & {$[\mathrm{Ca}]_{\mathrm{aq}}$. } & {$[\mathrm{Sr}]_{\mathrm{aq}}$.} & {$[\mathrm{Sr}]_{\mathrm{aq}}$.} & {$[\mathbf{C a}]_{\text {solid }}$} & {$[\mathrm{Sr}]_{\text {solid }}$} & $\mathrm{Sr}$ & $\mathrm{Sr} / \mathrm{Ca}$ in & $\mathbf{D}_{\text {Sr }, \text { gypsum }}$ \\
\hline ini. & end & ini. & end & & & incorporation & gypsum & \\
\hline$(\mathrm{mmol} / \mathrm{L})$ & $(\mathrm{mmol} / \mathrm{L})$ & $(\mathrm{mmol} / \mathrm{L})$ & $(\mathrm{mmol} / \mathrm{L})$ & $(\mathrm{mmol})$ & $(\mathrm{mmol})$ & (\%) & (\% \%ol) & \\
\hline 66.7 & 19.6 & 0.2 & 0.16 & 0.93 & $0.83 .10^{-3}$ & 20.2 & 0.09 & 0.10 \\
\hline 66.1 & 20.6 & 0.3 & 0.25 & 0.91 & $1.15 .10^{-3}$ & 18.8 & 0.12 & 0.10 \\
\hline 65.9 & 22.4 & 0.5 & 0.4 & 0.87 & $2.1 .10^{-3}$ & 20.6 & 0.24 & 0.13 \\
\hline 66.3 & 17.6 & 0.5 & 0.31 & 0.97 & $3.82 .10^{-3}$ & 37.7 & 0.39 & 0.22 \\
\hline 214.6 & 119.7 & 3.0 & 2.4 & 1.95 & $13.0 .10^{-3}$ & 21.2 & 0.67 & 0.34 \\
\hline 222.2 & 114.1 & 1.0 & 0.92 & 2.14 & $2.67 .10^{-3}$ & 12.7 & 0.12 & 0.15 \\
\hline 223.6 & 146.5 & 1.2 & 0.99 & 2.00 & $5.55 .10^{-3}$ & 17.6 & 0.28 & 0.40 \\
\hline 222.5 & 119.0 & 1.8 & 1.5 & 2.08 & $6.28 .10^{-3}$ & 17.6 & 0.30 & 0.24 \\
\hline 264.1 & 162.6 & 2.45 & 2.4 & 2.20 & $1.68 .10^{-3}$ & 3.1 & 0.08 & 0.05 \\
\hline 309.4 & 192.5 & 0.99 & 0.89 & 2.49 & $2.05 .10^{-3}$ & 9.7 & 0.08 & 0.18 \\
\hline
\end{tabular}

Table SI-3: Experiments of ${ }^{226} \mathrm{Ra}$ incorporation in celestite at equilibrium (recrystallization experiments).

\begin{tabular}{|c|c|c|c|c|c|}
\hline & $\begin{array}{c}\text { Duration } \\
\text { (days) }\end{array}$ & $\begin{array}{c}\mathrm{N} \text { recristallized } \\
\left(\text { mol. } L^{-1}\right)\end{array}$ & $\begin{array}{c}\left.{ }^{[226} \mathrm{Ra}\right] \\
\left(\text { nmol. } L^{-1}\right)\end{array}$ & $\mathrm{xRa}(\mathrm{ss})$ & $\begin{array}{c}\mathrm{D}_{\mathrm{Ra}} \\
\text { celestite }\end{array}$ \\
\hline \multicolumn{6}{|l|}{$\begin{array}{l}\text { Synthetic } \\
\text { celestite }\end{array}$} \\
\hline \multirow[t]{9}{*}{$\mathrm{I}-\mathrm{CS} 1$} & 0 & 0 & 15 & - & - \\
\hline & 0.08 & $2.74 .10^{-9}$ & 14 & $6.05 .10^{-1}$ & 3267.86 \\
\hline & 0.16 & $5.54 .10^{-8}$ & 13 & $4.18 .10^{-2}$ & 2320.06 \\
\hline & 1 & $3.50 .10^{-7}$ & 11 & $1.25 .10^{-2}$ & 794.75 \\
\hline & 7 & $2.47 .10^{-6}$ & 8 & $3.05 .10^{-3}$ & 270.93 \\
\hline & 18 & $6.43 .10^{-6}$ & 7 & $1.36 .10^{-3}$ & 141.25 \\
\hline & 30 & $1.08 .10^{-5}$ & 6 & $8.37 .10^{-4}$ & 91.50 \\
\hline & 66 & $2.41 .10^{-5}$ & 6 & $4.01 .10^{-4}$ & 48.44 \\
\hline & 119 & $4.39 .10^{-\mathrm{d}}$ & 5 & $2.31 .10^{-4}$ & 30.40 \\
\hline \multirow[t]{8}{*}{$\mathrm{I}-\mathrm{CS} 2$} & 0 & 0 & 14 & - & - \\
\hline & 1 & $3.41 .10^{-7}$ & 9 & $1.38 .10^{-2}$ & 1080.11 \\
\hline & 2 & $6.821 .10^{-7}$ & 8 & $7.96 .10^{-3}$ & 673.03 \\
\hline & 4 & $1.37 .10^{-6}$ & 7 & $4.66 .10^{-3}$ & 441.98 \\
\hline & 7 & $2.40 .10^{-6}$ & 7 & $2.94 .10^{-3}$ & 307.34 \\
\hline & 10 & $3.44 .10^{-6}$ & 6 & $2.24 .10^{-3}$ & 259.64 \\
\hline & 16 & $5.53 .10^{-6}$ & 5 & $1.55 .10^{-3}$ & 207.21 \\
\hline & 31 & $1.07 .10^{-5}$ & 5 & $7.72 .10^{-4}$ & 98.64 \\
\hline
\end{tabular}




\begin{tabular}{|c|c|c|c|c|c|}
\hline & $\begin{array}{l}\text { Duration } \\
\text { (days) }\end{array}$ & $\begin{array}{c}\mathrm{N} \text { recristallized } \\
\left(\text { mol. } L^{-1}\right)\end{array}$ & $\begin{array}{c}\left.{ }^{226} \mathrm{Ra}\right] \\
\left(\text { nmol. } L^{-1}\right)\end{array}$ & $\mathrm{xRa}(\mathrm{ss})$ & $\begin{array}{c}\mathrm{D}_{\mathrm{Ra}} \\
\text { celestite }\end{array}$ \\
\hline & 49 & $1.71 .10^{-5}$ & 5 & $5.33 .10^{-4}$ & 80.05 \\
\hline & 64 & $2.26 .10^{-5}$ & 4 & $4.17 .10^{-4}$ & 67.16 \\
\hline & 129 & $4.60 .10^{-5}$ & 4 & $2.15 .10^{-4}$ & 38.98 \\
\hline & 182 & $6.59 .10^{-5}$ & 4 & $1.48 .10^{-4}$ & 26.05 \\
\hline \multirow[t]{11}{*}{ I-CS3 } & 0 & 0 & 29 & - & - \\
\hline & 1 & $3.44 .10^{-7}$ & 19 & $3.02 .10^{-2}$ & 1178.03 \\
\hline & 2 & $6.94 .10^{-7}$ & 17 & $1.77 .10^{-2}$ & 761.50 \\
\hline & 5 & $1.75 .10^{-6}$ & 15 & $7.91 .10^{-3}$ & 371.16 \\
\hline & 7 & $2.48 .10^{-6}$ & 15 & $5.47 .10^{-3}$ & 251.17 \\
\hline & 9 & $3.22 .10^{-6}$ & 14 & $4.52 .10^{-3}$ & 221.18 \\
\hline & 16 & $5.78 .10^{-6}$ & 13 & $2.79 .10^{-3}$ & 154.12 \\
\hline & 28 & $1.02 .10^{-5}$ & 11 & $1.70 .10^{-3}$ & 103.91 \\
\hline & 40 & $1.47 .10^{-5}$ & 12 & $1.18 .10^{-3}$ & 71.26 \\
\hline & 62 & $2.31 .10^{-5}$ & 11 & $7.88 .10^{-4}$ & 51.62 \\
\hline & 159 & $5.99 .10^{-5}$ & 11 & $2.94 .10^{-4}$ & 18.23 \\
\hline
\end{tabular}




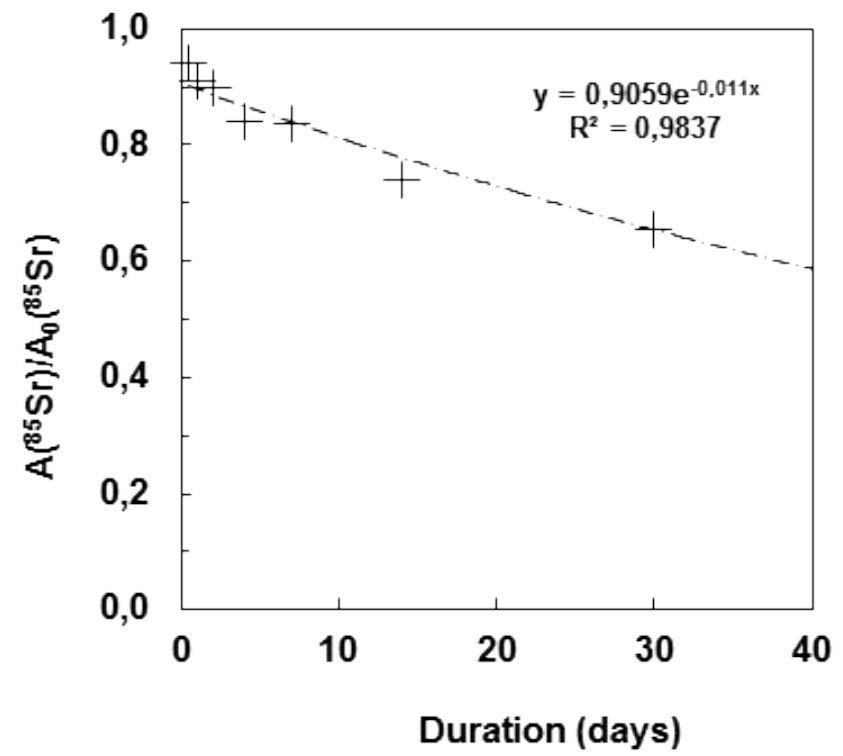

Figure SI-1: Evolution of $\mathrm{A}\left({ }^{85} \mathrm{Sr}\right)(\mathrm{t}) / \mathrm{A}_{0}\left({ }^{85} \mathrm{Sr}\right)$ ratio with time in solution at equilibrium with celestite

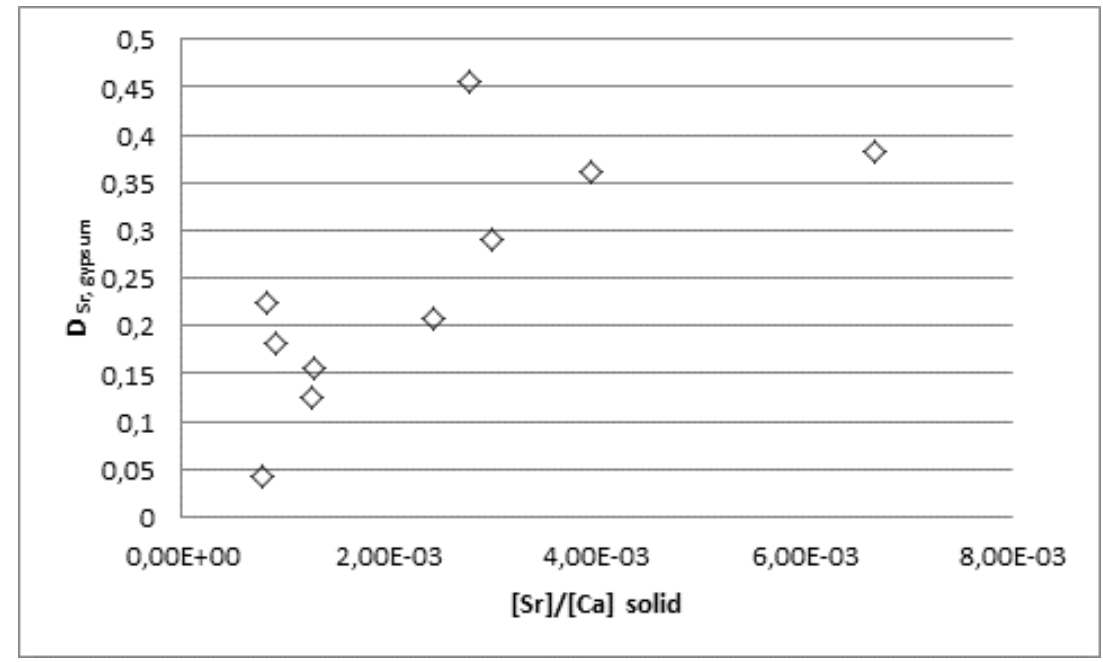

Figure SI-2: Evolution of $\mathrm{D}_{\mathrm{Sr}}$, gypsum with [Sr]/[Ca] molar ratio in gypsum. 


\section{Calculation of non-ideality parameters:}

According to the Bruno et al's approach ${ }^{30}$, the activity coefficients of the two end-members $\mathrm{SrSO}_{4}$ and $\mathrm{RaSO}_{4}$ are defined by the following equations:

$\operatorname{Lnf}_{\mathrm{SrSO} 4}=x_{\mathrm{RaSO} 4}{ }^{2}\left[a_{0}+a_{1}\left(3 x_{\mathrm{SrSO} 4}-x_{\mathrm{RaSO} 4}\right)+a_{2}\left(x_{\text {SrSO } 4}-x_{\text {RaSO } 4}\right) \cdot\left(5 x_{\mathrm{SrSO} 4}-x_{\mathrm{RaSO} 4}\right)\right]$

$\operatorname{Lnf}_{\text {RaSO } 4}=x_{\mathrm{SrSO}}^{2}\left[a_{0}+a_{1}\left(3 x_{\text {RaSO } 4}-x_{\text {SrSO } 4}\right)+a_{2}\left(x_{\text {RaSO } 4}-x_{\text {SrSO } 4}\right) \cdot\left(5 x_{\text {RaSO } 4}-x_{\text {SrSO } 4}\right)\right]$

where $\mathrm{a}_{0}, \mathrm{a}_{1}$ and $\mathrm{a}_{2}$ are Redlich-Kistler dimensionless non-ideality interaction parameters. In the case of ideal solid solution all the interaction parameters equal 0 .

In the case of regular solid solution, $\mathrm{a}_{\mathrm{o}}$ is the only parameter different of zero. According to Curti's study $^{15}, a_{0}$ parameter was calculated using Roozeboom diagram ${ }^{31}$ with plotting xRa(aq) versus xRa (ss).

$\mathrm{X}_{\mathrm{Ra}}(\mathrm{aq})$ is defined by the following relation ${ }^{15}$ :

$x_{R a}(a q)=\frac{K_{s, R a S O 4} x_{R a}(s s) f_{R a}}{K_{s, R a S O 4} x_{R a}(s s) f_{R a}+K_{s, S r S O 4} f_{S r}\left(1-x_{R a}(s s)\right)}$

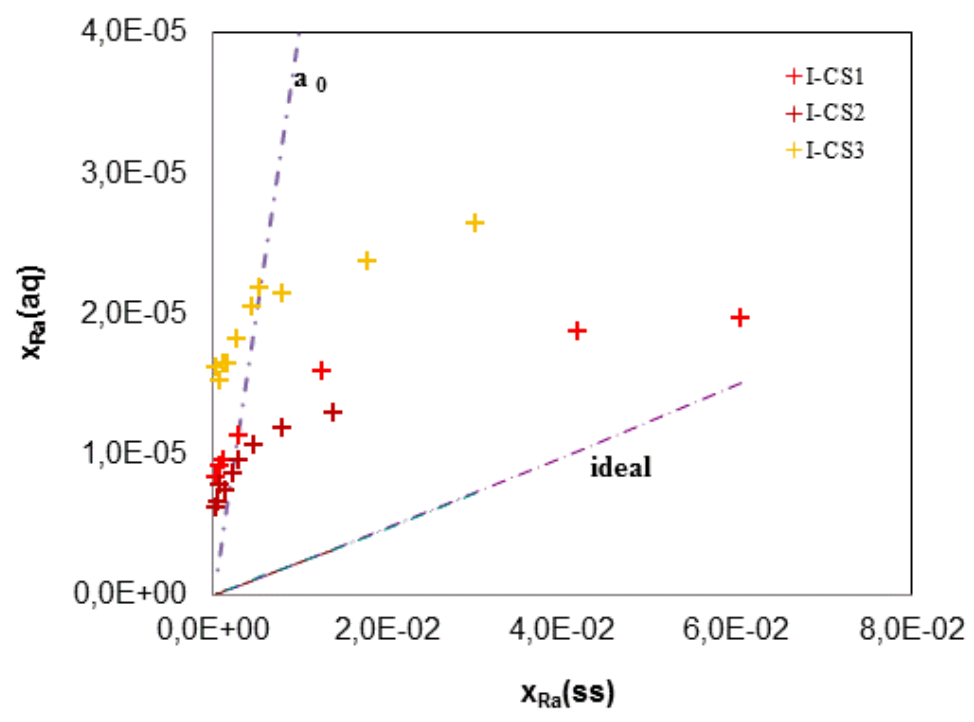

Figure SI-3: Determination of $\mathrm{a}_{0}$ parameter in a Roozeboom diagram with plotting $\mathrm{x}_{\mathrm{Ra}}(\mathrm{aq})$ versus $\mathrm{x}_{\mathrm{Ra}}(\mathrm{ss})$ obtained from experimental data which duration time is superior to 7 days.

$\mathrm{a}_{0}$ is estimated at 3 , corresponding to a Margules parameter of $1834 \mathrm{cal} / \mathrm{mol}$, where Margules parameter, $\mathrm{W}$, is related to $\mathrm{a}_{0}$ by the following relation: 
$\mathrm{W}=\mathrm{RT} . \mathrm{a}_{0}$ with $\mathrm{R}$, the constant of perfect gaz. 